\begin{tabular}{|l|l|l||}
\hline \multicolumn{2}{|c|}{ PublisherInfo } \\
\hline \hline PublisherName & $:$ & BioMed Central \\
\hline \hline PublisherLocation & $:$ & London \\
\hline \hline PublisherImprintName & $:$ & BioMed Central \\
\hline \hline
\end{tabular}

\title{
Articles selected by Faculty of 1000: sorghum genome sequencing; carbohydrate microarrays; metabolite profiling in fungi; in silico fate mapping; investigating cri du chat syndrome using array $\mathrm{CGH}$
}

\begin{tabular}{|l|l|l||}
\hline \multicolumn{2}{|c||}{ ArticleInfo } \\
\hline \hline ArticleID & $:$ & 3506 \\
\hline \hline ArticleDOI & $:$ & $10.1186 /$ gb-2005-6-3-313 \\
\hline \hline ArticleCitationID & $:$ & 313 \\
\hline \hline ArticleSequenceNumber & $:$ & 18 \\
\hline \hline ArticleCategory & $:$ & Paper report \\
\hline \hline ArticleFirstPage & $:$ & 1 \\
\hline \hline ArticleLastPage & $:$ & 3 \\
\hline \hline & $:$ & RegistrationDate : 2005-2-9 \\
ArticleHistory & $:$ & OnlineDate $\quad$ 2005-2-9 \\
\hline
\end{tabular}




\begin{tabular}{|l||l|l|}
\hline ArticleCopyright & $:$ & BioMed Central Ltd2005 \\
\hline \hline ArticleGrants & $:$ & \\
\hline \hline ArticleContext & $:$ & 130596633 \\
\hline
\end{tabular}

\section{Sorghum genome sequencing}

A selection of evaluations from Faculty of $\mathbf{1 0 0 0}$ covering sorghum genome sequencing, carbohydrate microarrays, metabolite profiling in fungi, in silico fate mapping and investigating cri du chat syndrome using array $\mathrm{CGH}$.

Sorghum genome sequencing by methylation filtration. Bedell JA, Budiman MA, Nunberg A, Citek RW, Robbins D, Jones J, Flick E, Rholfing T, Fries J, Bradford K, et al. PLoS Biol 2005, 3:e13.

For the Faculty of 1000 evaluation of this article please see: http://genomebiology.com/reports/F1000/ gb-2005-6-3-313.asp\#Bedell

\section{Carbohydrate microarrays}

The use of carbohydrate microarrays to study carbohydrate-cell interactions and to detect pathogens. Disney MD, Seeberger PH. Chem Biol 2004, 11:1701-1707.

For the Faculty of 1000 evaluation of this article please see: http://genomebiology.com/reports/F1000/ gb-2005-6-3-313.asp\#Disney

\section{Metabolite profiling in fungi}

Metabolite profiling of fungi and yeast: from phenotype to metabolome by MS and informatics. Smedsgaard J, Nielsen J. J Exp Bot 2005, 56:273-286.

For the Faculty of 1000 evaluation of this article please see: http://genomebiology.com/reports/F1000/ gb-2005-6-3-313.asp\#Smedsgaard 


\section{In silico fate mapping}

A gene regulatory network model for cell-fate determination during Arabidopsis thaliana flower development that is robust and recovers experimental gene expression profiles. Espinosa-Soto $\mathrm{C}$, Padilla-Longoria P, Alvarez-Buylla ER. Plant Cell 2004, 16:2923-2939.

For the Faculty of 1000 evaluation of this article please see: http://genomebiology.com/reports/F1000/ gb-2005-6-3-313.asp\#Espinosa-Soto

\section{Investigating cri du chat syndrome using array $\mathrm{CGH}$}

High-resolution mapping of genotype-phenotype relationships in cri du chat syndrome using array comparative genomic hybridization. Zhang X, Snijders A, Segraves $\mathrm{R}$, Zhang X, Niebuhr A, Albertson D, Yang H, Gray J, Niebuhr E, Bolund L, Pinkel D. Am J Hum Genet 2005, 76:312-326.

For the Faculty of 1000 evaluation of this article please see: http://genomebiology.com/reports/F1000/ gb-2005-6-3-313.asp\#Zhang

This PDF file was created after publication. 